\title{
STUDY OF THE METAMORPHIC EVOLUTION OF A CARBONATE-BEARING METAPERIDOTITE FROM THE SIDIRONERO COMPLEX (CENTRAL RHODOPE, GREECE) USING P-T AND P(T)- $\mathrm{X}_{\mathrm{CO}_{2}}$ PSEUDOSECTIONS
}

\section{Mposkos E. and Baziotis I.}

National Technical University of Athens, Department of Mining and Metallurgical Engineering, Section of Geological Sciences, Heroon Polytechniou 9, 15780,Athens, Greece, mposkos@metal.ntua.gr, baziotis@metal.ntua.gr

\begin{abstract}
The carbonate-bearing metaperidotite from Sidironero Complex, north of the Xanthi town is composed primarily of olivine and orthopyroxene megacrysts and of Ti-clinohumite, tremolite, chlorite, dolomite, magnesite, talc, antigorite and spinel group minerals. The metaperidotite underwent a prograde HP metamorphism probably isofacial with the neighboring amphibolitized eclogites. Calculated $P-T$ and $P(T)-X_{\mathrm{CO}_{2}}$ phase diagram sections (pseudosections) for the bulk rock composition showed that $X_{\mathrm{CO} 2}$ in the fluid phase was extremely low $(\leq 0.008)$ at the first stages of the metamorphism and increased up to 0.022 at the peak P-T conditions $\sim 1.5 \mathrm{GPa}$ and $690^{\circ} \mathrm{C}$. The prograde metamorphism probably started from a hydrated and carbonated assemblage including talc + chlorite + magnesite +dolomite and proceeded with tremolite and antigorite formation before olivine growth, and orthopyroxene formation after olivine growth (Ol-1). Matrix dolomite, breakdown of chlorite (Chl-1) to Cr-spinel+olivine and of Ti-clinohumite to olivine $+M g$-ilmenite occurred during decompression. The P-T path is constrained by the absence of clinopyroxene in the metaperidotite.
\end{abstract}

Key words: Carbonate-bearing metaperidotite, pseudosections, Rhodope, Sidironero.

\section{Introduction}

Carbonate-bearing peridotites in metamorphic terrains provide excellent information about $P$ - $T$ regimes and fluid phase composition. Phase relationships for carbonate-bearing peridotites of lherzolithic bulk compositions are very useful for deciphering details of the metamorphic evolution of a terrain. Thus, peridotites can bear important geodynamic implications that are mostly obscure in other rock types.

The objective of this paper is to describe the successive formation of mineral phase assemblages in the frame of the metamorphic evolution of a carbonate-bearing chlorite-spinel metaperidotite from the HP/UHP Sidironero Complex in the area of Gorgona, north of Xanthi. We calculate P-T-X $\mathrm{CO}_{\mathrm{CO}}$ pseudosections in the $\mathrm{CaO}-\mathrm{FeO}-\mathrm{MgO}-\mathrm{Al}_{2} \mathrm{O}_{3}-\mathrm{SiO}_{2}-\mathrm{CO}_{2}-\mathrm{H}_{2} \mathrm{O}$ (CFMAS-fluid) system using the Perplex software (ver.06 Jul 2006; Connoly, 2009) and the internally-consistent thermodynamic database (Holland and Powell 1998, revised 2002). Calculated P-T (for fixed $\mathrm{X}_{\mathrm{CO} 2}$ ) and $\mathrm{P}(\mathrm{T})-\mathrm{X}_{\mathrm{CO} 2}$ (for specific geothermal gradient) pseudosections for the bulk-rock composition of the studied metaperidotite are able to illustrate the stability fields of certain mineral assemblages and to evaluate the composition of the fluid phase in the successive stages of the metamorphic evolution of the metaperidotite. 


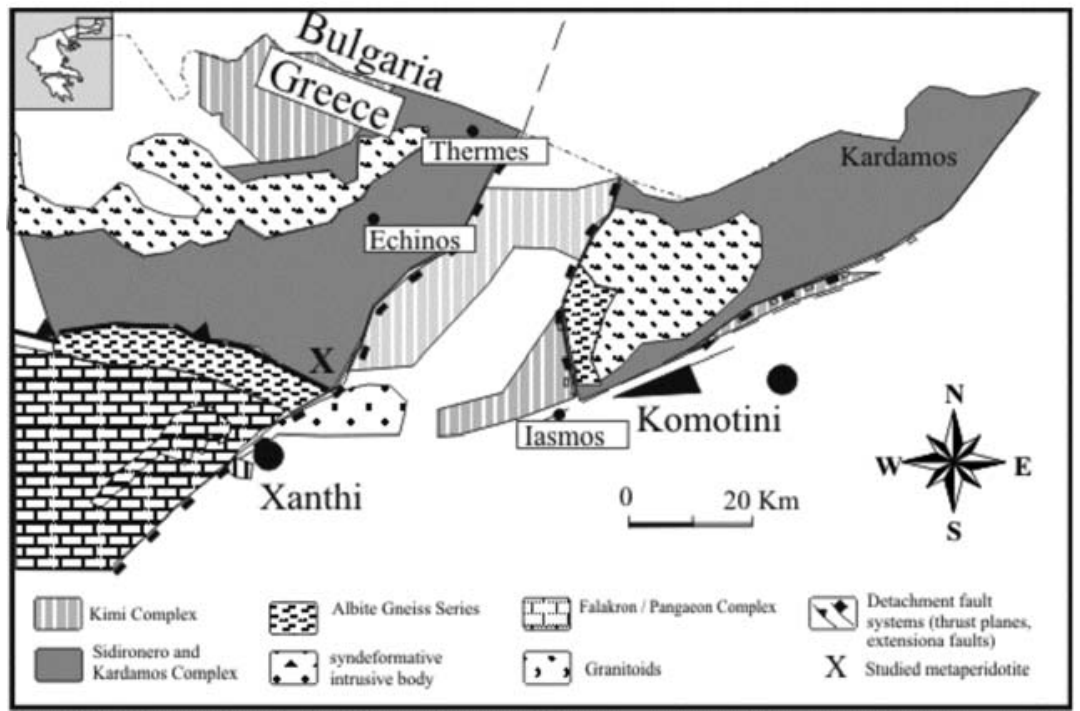

Fig. 1: Geological map of Xanthi area showing the location of the carbonate-bearing metaperidotite (Krohe and Mposkos, 2002).

\section{Geological setting}

The Rhodope HP Domain extends over large areas of northern Greece and southern Bulgaria. The Greek part of Rhodope is subdivided by Mposkos and Krohe (2000) into several tectonometamorphic complexes that are bounded by thrust and normal faults. These segments differ in P-T conditions during their HP metamorphism, shape of P-T paths and timing of exhumation. The Sidironero complex, where the studied carbonate-bearing metaperidotite occurs, consists predominantly of migmatitic pelitic gneisses and orthogneisses, with intercalations of amphibolitized eclogites, marbles and rare serpentinized peridotites. The least serpentinized lense of ultramafic rocks from Sidironero Complex in the Xanthi area is the carbonate-bearing metaperidotite from Gorgona location (Fig. 1). It is a small body $\sim 200 \mathrm{~m}$ wide and $\sim 500 \mathrm{~m}$ long, surrounded by orthogneisses. The Sidironero Complex records a Late-Jurassic HP/UHP metamorphism similar to the overlying Kimi Complex documented by the presence of partially amphibolitized eclogites and diamond inclusions in garnet from pelitic gneisses (Mposkos and Kostopoulos, 2001; Perraki et al., 2004, 2006; Liati, 2005; Liati and Mposkos, 1990), but experienced an additional weaker Eocene metamorphic overprint (Liati, 2005; Bosse et al., 2009).

\section{Petrography and mineral chemistry}

The metaperidotite is composed primarily of coarse grained (3-20 $\mathrm{mm}$ in size) olivine and orthopyroxene and medium to fine grained $(0.9-0.01 \mathrm{~mm}$ in size) Ti-clinohumite, tremolite, chlorite, dolomite, magnesite, talc, antigorite, light brown to opaque minerals of the spinel group and pentlandite. Anthophyllite replacing orthopyroxene is reported by Kassoli-Fournaraki et al. (1995).

Olivine $\left(\mathrm{Fo}_{90-92}\right)$ occurs in two generations that overgrow each other. The first generation $(\mathrm{Ol}-1$; abbreviations after Martin, 1998) forms irregularly shaped megacrysts commonly rich in fluid inclusions 2 to $5 \mu \mathrm{m}$ in size. Most of the inclusions are composite and contain one or two solid phases. Micro-Raman spectroscopy showed that the solid phases are talc and magnesite. Ol-1 contains in- 
clusions of tremolite, dolomite, talc, magnesite, chlorite, Cr-magnetite and ferrit-chromite (Fig. 2a). The second olivine generation (Ol-2) contains inclusions of light brown $\mathrm{Cr}$-spinel, dolomite and $\mathrm{Al}-$ bearing tremolite $\left(\mathrm{Al}_{2} \mathrm{O}_{3}\right.$ up to $\left.5.4 \mathrm{wt} \%\right)$. In places $\mathrm{Ol}-2$ overgrows $\mathrm{Ol}-1$ as indicated by inclusions of spinel at the outer parts of some olivine megacrysts (Fig. 2b). These inclusions of light brown chromian-spinel are commonly oriented in the olivine host suggesting simultaneous crystallization of chromian-spinel and host olivine, probably as decomposition products of chlorite. Ol-2 and light brown chromian-spinel are replaced by retrograde diablastic chlorite and magnesite (Fig. 2c).

Orthopyroxene $\left(\mathrm{En}_{89-90}\right)$ forms sub-idiomorphic prismatic megacrysts. Inclusions of chlorite, tremolite, dolomite, magnesite and olivine in orthopyroxene are common (Figs. 2d). Olivine inclusions in orthopyroxene show corroded edges (Fig. 2e), indicating that orthopyroxene grew from olivine (O11). Cr-magnetite and ferrit-chromite also occur as inclusions in orthopyroxene; but light brown chromian-spinels which are common inclusions in Ol-2 were not observed. This suggests that the formation of orthopyroxene preceded that of the Ol-2. Rarely orthopyroxene occurs also as inclusions in olivine (Fig. 2f).

Ti-clinohumite occurs as inclusions in olivine, orthopyroxene, tremolite and ferrit-chromite. Matrix Ti-clinohumite forms granoblastic megacrysts up to $0.8 \mathrm{~mm}$ in size in epitaxial intergrowth with olivine, both minerals showing contemporaneous extinction in thin section. Segments of the clinohumite megacryst are decomposed to olivine and lamellar Mg-ilmenite (Fig. 3a). Representative composition of Ti-clinohumite is given in table $1 . \mathrm{TiO}_{2}$ content ranges from 4.07 to $4.69 \mathrm{wt} \%$ and $\mathrm{F}$ content from 1.33 to $1.67 \mathrm{wt} \%$.

Two generations of chlorite are distinguished. The first generation (Chl-1) occurs as inclusions in orthopyroxene, olivine, Ti-clinohumite, dolomite and ferrit-chromite (Fig. 2d). The second generation (Chl-2) is retrograde and forms diablastic flakes replacing olivine (Ol-2) and light brown chromian spinel. It is associated with retrograde talc, magnesite and tremolite (Fig. 2c). Olivine grains with corroded edges and rods of spinel aggregates are included in Chl-2. The two generations of chlorite distinguished on textural criteria show remarkable differences in their chemical composition. Chl-1 shows higher $\mathrm{Cr}_{2} \mathrm{O}_{3}$ and lower $\mathrm{Al}_{2} \mathrm{O}_{3}$ contents compared to Chl-2 (Tab. 1). The $\mathrm{Cr}_{2} \mathrm{O}_{3}$ and $\mathrm{Al}_{2} \mathrm{O}_{3}$ contents in Chl-1 range from 2.33 to $5.79 \mathrm{wt} \%$ and 12.07 to $13.68 \mathrm{wt} \%$ and in Chl-2 from 0.71 to $1.63 \mathrm{wt} \%$ and 16.99 to $20.33 \mathrm{wt} \%$ respectively.

Inclusions of tremolite ( $\mathrm{Tr}-1)$ in olivine (O1-1), orthopyroxene and dolomite are common (Fig. $2 \mathrm{c}, 3 \mathrm{~b}$ ). Al-bearing tremolite ( $\mathrm{Tr}-2)$ occurs as inclusions in $\mathrm{Ol}-2$ and in the matrix. It is associated with Ol-2 and light brown chromian spinel, and commonly overgrows tremolite- 1 as indicates the increase in $\mathrm{Al}_{2} \mathrm{O}_{3}$ content from the core $(0.2 \mathrm{wt} \%)$ to the rim (5.36 wt \%, Tab.1). Retrograde matrix tremolite ( $\mathrm{Tr}-3)$ is associated with matrix chlorite (Chl-2), magnesite (Mgs-2) and talc and replaces orthopyroxene, olivine and dolomite. $\mathrm{Tr}-1$ is low in aluminum. Most tremolite inclusions in $\mathrm{Ol}-1$ and orthopyroxene have $\mathrm{Al}_{2} \mathrm{O}_{3}$ contents less than $0.15 \mathrm{wt} \%$ and those included in matrix dolomite of less than $0.6 \mathrm{wt} \%$. In Tr-2, which is associated with Ol-2 and light brown spinel, the $\mathrm{Al}_{2} \mathrm{O}_{3}$ content ranges from 3.2 to $5.4 \mathrm{wt} \%$. Retrograde tremolite (Tr-3) again contains less than $0.10 \mathrm{wt} \% \mathrm{Al}_{2} \mathrm{O}_{3}$. $\mathrm{The} \mathrm{Mg} /(\mathrm{Mg}+\mathrm{Fe})$ ratio in all tremolites ranges from 0.94 to 0.95 .

Dolomite inclusions in Ol-2 contain inclusions of magnesite, commonly with corroded edges (Fig. 3c). Matrix dolomite is in textural equilibrium with olivine and orthopyroxene. It contains inclusions of tremolite (Tr-1), chlorite (Chl-1), magnesite (Mgs-1) and olivine (Ol-1) (Fig. 3b). Dolomite contains $\mathrm{FeO}$ 1.4-1.6 wt\%. Two magnesite generations are distinguished based on textural criteria. Mgs1 occurs as inclusions in olivine, orthopyroxene and dolomite. Matrix magnesite (Mgs-2) is associated with matrix chlorite (Chl-2); both minerals are formed during replacement of olivine and 

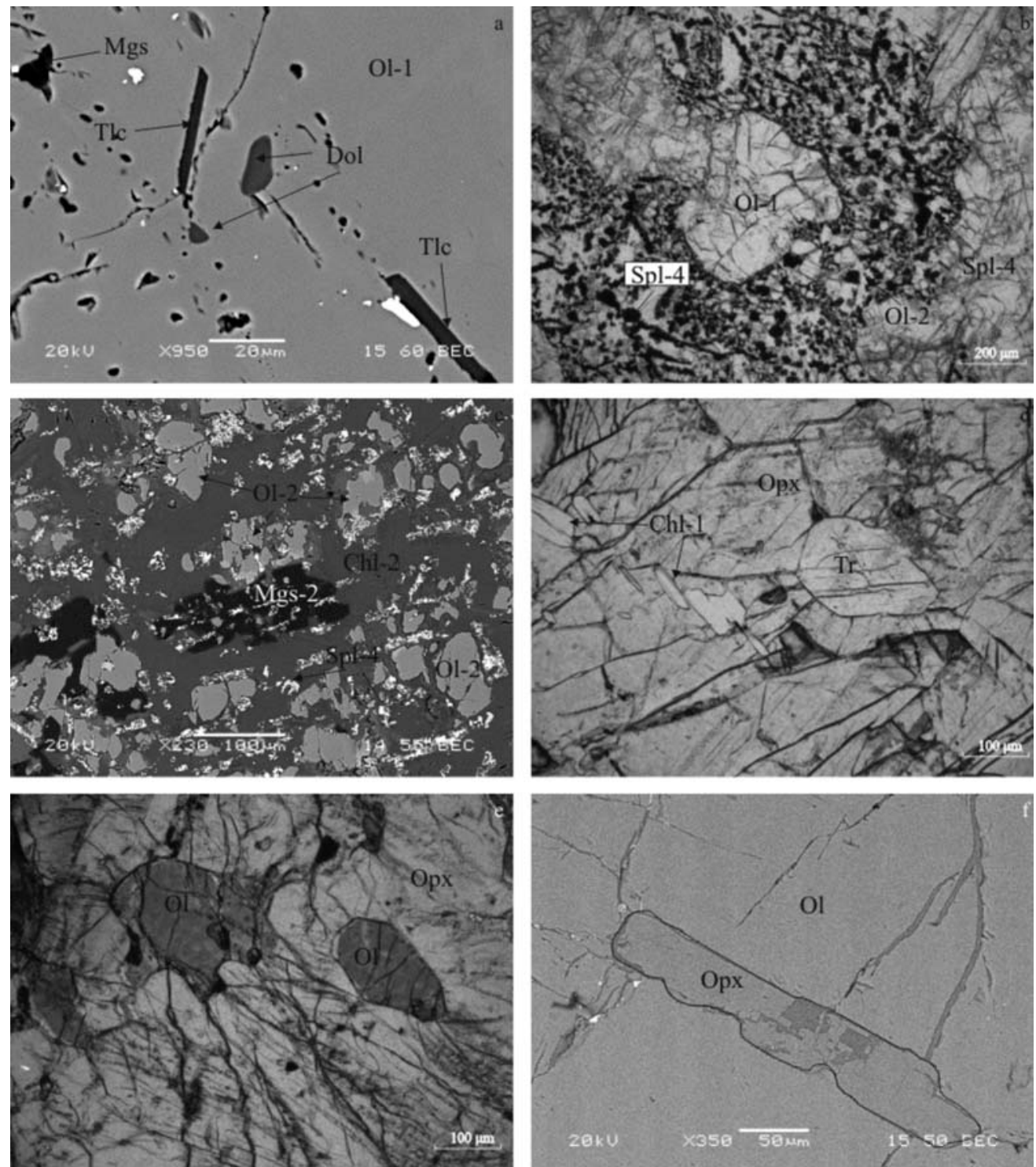

Fig. 2: (a) Inclusions of talc (Tlc), dolomite (Dol) and magnesite (Mgs) in olivine (Ol-1). (b) Two generations of olivine. Ol-2 with inclusions of $\mathrm{Cr}$-spinel (Spl-4) is overgrown $\mathrm{Ol}-1$, which is free of spinel inclusions. (c) Spinel aggregates (Spl-4) and olivine (Ol-2) are replaced by secondary chlorite (Chl-2) and magnesite (Mgs2). (d) Inclusions of chlorite (Chl-1) and tremolite (Tr) in orthopyroxene. (e) Inclusions of olivine (Ol-1) in orthopyroxene (Opx). The inclusions show corroded edges. (f) Inclusion of orthopyroxene in olivine. (a), (c), (f): Backscattered electron (BSE) image . (b), (d), (e): Micropphotographs. 
Table 1. Representative mineral compositions of tremolite ( $\mathrm{Tr}$ ), chlorite (Chl), Ti-clinohumite (Ti$\mathrm{Chu}$ ) and spinel group minerals $(\mathrm{Spl})$ of the carbonate-bearing metaperidotite from Gorgona (N Xanthi area).

\begin{tabular}{|c|c|c|c|c|c|c|c|c|c|c|c|}
\hline $\mathbf{A} / \mathbf{A}$ & 1 & 2 & 3 & 4 & 5 & & 6 & 7 & 8 & 9 & 10 \\
\hline & $\operatorname{Tr}-1^{c}$ & Tr-2 & Chl-1 & Chl-2 & Ti-Chu & & Spl-1 ${ }^{c}$ & Spl- $4^{\mathrm{r}}$ & Spl-2 & Spl-3 ${ }^{c}$ & Spl- $4^{\mathrm{r}}$ \\
\hline $\mathrm{SiO}_{2}$ & 58.30 & 55.09 & 32.54 & 31.02 & 35.88 & $\mathrm{TiO}_{2}$ & - & - & - & 2.49 & - \\
\hline $\mathrm{TiO}_{2}$ & - & - & - & - & 4.69 & $\mathrm{Al}_{2} \mathrm{O}_{3}$ & 35.69 & 54.07 & 1.45 & 13.71 & 61.57 \\
\hline $\mathrm{Al}_{2} \mathrm{O}_{3}$ & 0.12 & 5.36 & 13.30 & 20.33 & - & $\mathrm{Cr}_{2} \mathrm{O}_{3}$ & 29.33 & 14.42 & 9.88 & 35.71 & 4.25 \\
\hline $\mathrm{Cr}_{2} \mathrm{O}_{3}$ & - & 0.04 & 5.79 & 0.71 & - & $\mathrm{Fe}_{2} \mathrm{O}_{3}$ & 3.871 & 1.221 & 58.991 & 15.681 & 5.221 \\
\hline $\mathrm{FeOt}$ & 2.24 & 1.78 & 1.05 & 2.48 & 8.41 & $\mathrm{FeO}$ & 19.731 & 11.241 & 24.891 & 25.331 & 4.251 \\
\hline $\mathrm{MnO}$ & 0.04 & - & 0.02 & 0.02 & 0.09 & $\mathrm{MnO}$ & 0.04 & - & 0.02 & 0.02 & - \\
\hline $\mathrm{MgO}$ & 23.0 & 21.27 & 33.35 & 32.65 & 48.08 & $\mathrm{MgO}$ & 11.77 & 19.20 & 3.27 & 7.15 & 23.54 \\
\hline $\mathrm{NiO}$ & 0.03 & 0.05 & 0.25 & 0.18 & 0.37 & $\mathrm{NiO}$ & - & - & 1.54 & 0.02 & - \\
\hline $\mathrm{CaO}$ & 13.52 & 13.52 & - & - & $1.59 *$ & $\mathrm{CaO}$ & - & - & - & - & - \\
\hline Total & 97.2 & 97.02 & 86.30 & 87.40 & 99.1 & Total & 100.47 & 100.15 & 100.04 & 100.23 & 100.54 \\
\hline $\mathrm{O}$ & 23 & 23 & 14 & 14 & + & $\mathrm{O}$ & 4 & 4 & 4 & 4 & 4 \\
\hline $\mathrm{Si}$ & 8.002 & 7.572 & 3.115 & 2.900 & 3.777 & $\mathrm{Ti}$ & - & - & - & 0.062 & - \\
\hline $\mathrm{Ti}$ & - & - & - & - & 0.371 & $\mathrm{Al}$ & 1.234 & 1.676 & 0.063 & 0.539 & 1.818 \\
\hline $\mathrm{Al}$ & 0.020 & 0.868 & 1.501 & 2.241 & - & $\mathrm{Cr}$ & 0.680 & 0.299 & 0.290 & 0.942 & 0.084 \\
\hline $\mathrm{Cr}$ & - & 0.010 & 0.438 & 0.053 & - & $\mathrm{Fe}^{3+}$ & 0.085 & 0.024 & 1.647 & 0.394 & 0.098 \\
\hline $\mathrm{Fe}^{2+}$ & 0.257 & 0.204 & 0.084 & 0.194 & 0.740 & $\mathrm{Fe}^{2+}$ & 0.484 & 0.247 & 0.771 & 0.706 & 0.121 \\
\hline $\mathrm{Mn}$ & 0.005 & - & 0.002 & 0.002 & 0.01 & $\mathrm{Mn}$ & 0.001 & - & - & - & - \\
\hline $\mathrm{Mg}$ & 4.709 & 4.357 & 4.758 & 4.550 & 7.545 & $\mathrm{Mg}$ & 0.515 & 0.753 & 0.181 & 0.355 & 0.879 \\
\hline $\mathrm{Ni}$ & 0.003 & 0.005 & 0.019 & 0.014 & 0.031 & $\mathrm{Ni}$ & - & - & 0.047 & - & - \\
\hline $\mathrm{Ca}$ & 1.990 & 1.997 & - & - & 0.528 & $\mathrm{Ca}$ & - & - & - & - & 0.007 \\
\hline
\end{tabular}

spinel at a retrograde stage of metamorphism (Fig. 2c). Matrix magnesite is also associated with talc, replacing olivine and orthopyroxene, or with tremolite, replacing olivine and dolomite. The $\mathrm{FeO}$ content in magnesite ranges from 4.2-5.2 wt $\%$, the $\mathrm{MnO}$ content from $0.23-0.24 \mathrm{wt} \%$ and the $\mathrm{CaO}$ content from $0.45-0.50 \mathrm{wt} \%$.

Four types of spinel group mineral are recognized. Spl-1 is dark-brown and occurs only as cores in zoned crystals (Fig. 3d). Spl-2 and -3 are Cr-magnetite and ferrit-chromite respectively and occur as single grains, or grain aggregates, in the matrix and as inclusions in olivine, orthopyroxene, tremolite and chlorite. Spl-4 is light brown, more or less chromian spinel and associated with olivine (Ol2 ) and rarely with tremolite ( $\mathrm{Tr}-2)$. It is also enclosed in matrix chlorite (Chl-2) and matrix magnesite (Mgs-2)(Fig. 2c). In zoned chromite grains, Spl-4 always forms the outer zone, with cores consisting of type-1 or type-3 spinel (Figs. 3d,e). However, zoning with Spl-4 core and Spl-3 rim also occurs as an alteration product. 

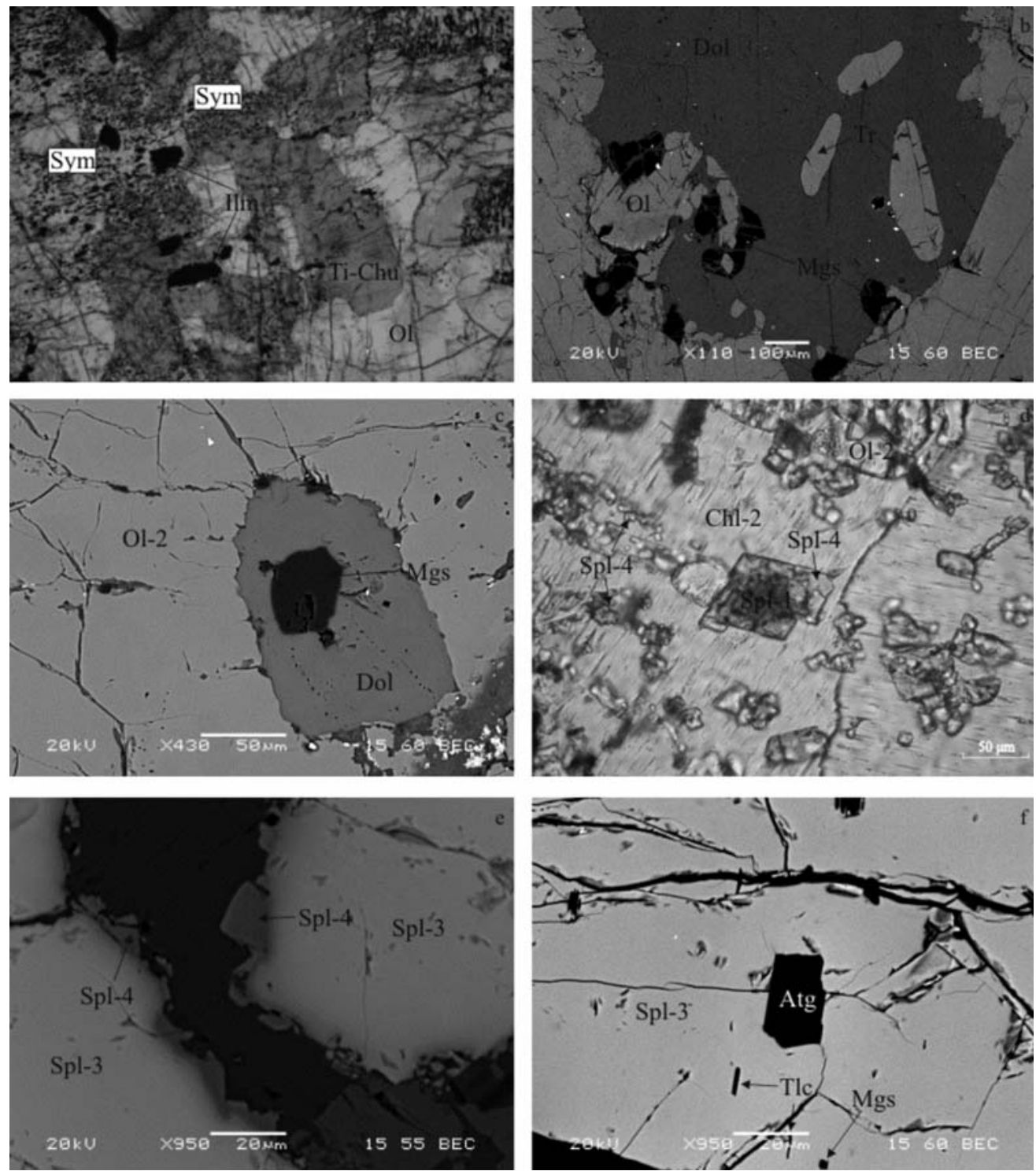

Fig. 3: (a) Ti-clinohumite (Ti-Chu) and olivine (Ol-1) intergrowth. Ti-clinohumite in part is decomposed to olivine+Mg-ilmenite (Sym). (b) Matrix dolomite (Dol) with inclusions of tremolite (Tr), magnesite (Mgs) and olivine (Ol). (c) Inclusion of dolomite in olivine (Ol-2). The dolomite inclusion contains inclusion of magnesite (Mgs) (d) Chromite (Spl-1) overgrown by Cr-spinel (Spl-4) is included in retrograde chlorite (Chl-2). (e) Ferrit-chromite (Spl-3) is overgrown by Cr-spinel (Spl-4). (f) Inclusions of talc (Tlc), magnesite (Mgs) and antigorite (Atg) in ferrit-chromite (Spl-3). (a), (d): Microphotographs. (b), (c), (e), (f): BSE image. 
The four types of Cr-spinel minerals distinguished by textural criteria also show remarkable differences in their chemical compositions, indicating growth of spinel minerals at different metamorphic conditions (Tab. 1). Spinel-1 has a $\mathrm{Cr} \#\left[\mathrm{Cr} /\left(\mathrm{Cr}+\mathrm{Al}+\mathrm{Fe}^{3+}\right)\right]$ ratio ranging from 0.34 to 0.43 and a $\mathrm{Mg} \#\left[\mathrm{Mg} /\left(\mathrm{Mg}+\mathrm{Fe}^{2+}\right)\right]$ ratio from 0.38 to 0.51 . It probably represents relics of the mantle protolith. Spinel-2 is Cr-magnetite with a Cr\# ranging from 0.17 to 0.18 . Spinel-3 is ferrit-chromite, with magnetite component $\left(\mathrm{Fe}^{+3} / \mathrm{R}^{+3}\right)$ ranging from 28 to $43 \%$ and $\mathrm{Al}$-spinel component from 0.03 to $38.3 \%$. It is characterized by low Mg-contents with $\mathrm{Mg}$ \# ranging from 0.11 to 0.30 . Spinel-4 is chromian spinel with $\mathrm{Cr} \#$ and $\mathrm{Mg}$ \# ranging from 0.04 to 0.24 and from 0.67 to 0.91 respectively. The compositional variation in spinel group minerals from Cr-magnetite to ferrit-chromite and chromian spinel, and the compositional zoning with increasing $\mathrm{Al}$ content, from the core to the rim in zoned grains suggest a prograde metamorphic evolution of the Gorgona metaperidotite from lower to higher grade conditions. Cr-magnetite is common in serpentinized peridotites at greenschist and ferritchromite at amphibolite facies conditions (Evans and Frost, 1975).

Talc is found as inclusions in Ol-1 and ferrit-chromite (Figs. 2a, 3f). Secondary talc forms unoriented flakes in the matrix and is associated with matrix magnesite and chlorite replacing olivine and orthopyroxene. Talc has the highest $\mathrm{Mg} /(\mathrm{Mg}+\mathrm{Fe})$ ratio $(0.97)$ of all the silicate minerals in the metaperidotite. The $\mathrm{Al}_{2} \mathrm{O}_{3}$ content is up to $0.10 \mathrm{wt} \%$ and $\mathrm{Cr}_{2} \mathrm{O}_{3}$ up to $0.06 \mathrm{wt} \%$. Primary antigorite is rare and is found only as single grain inclusions in ferrit-chromite (Fig. 3f) and olivine. Retrograde serpentine replaces olivine megacrysts along fractures and is associated with retrograde chlorite and talc. The antigorite inclusions in ferrit-chromite have $\mathrm{FeO}$ contents ranging from 1.15 to 5.13 and $\mathrm{Cr}_{2} \mathrm{O}_{3}$ contents up to $0.75 \mathrm{wt} \%$. Mg-Ilmenite ( $\mathrm{MgO} 7.60-8.43 \mathrm{wt} \%$ ) occurs as inclusions in ferrit-chromite and Ti-clinohumite and as oriented laths in olivine; the latter are decomposition products of former Ti-clinohumite (Fig. 3a).

\section{Discussion}

\subsection{Metamorphic evolution}

The inclusions of magnesite, dolomite, chlorite, talc, tremolite, antigorite in ferrit-chromite, olivine and orthopyroxene and the chemical compositions of zoned spinel minerals with increasing Al content toward the rim (Table 1) demonstrate very convincingly the prograde metamorphic character of the Gorgona metaperidotite. The prograde metamorphic evolution probably started from hydrated and carbonated assemblage including talc + chlorite + magnesite + dolomite (+ antigorite) $+\mathrm{Cr}-$ magnetite. We assume that the metamorphic evolution occurred in a subduction related environment as is suggested by the presence of amphibolitized eclogites in the same locality (Liati and Mposkos, 1990). Minimum pressures of $1.3 \mathrm{GPa}$ and temperatures of $650-700^{\circ} \mathrm{C}$ are obtained from the amphibolitized eclogites for the HP event (Liati and Mposkos, 1990). In the tectonometamorphically equivalent Kimi area (eastern Rhodope) P-T conditions of $\sim 700^{\circ} \mathrm{C}$ and $>1.75 \mathrm{GPa}$ are reported for the eclogite stage followed by a temperature increase $\left(\sim 750^{\circ} \mathrm{C}\right)$ during the first stage of decompression (Bauer et al., 2007). Therefore, a relatively cool subduction gradient of around $12^{\circ} \mathrm{C} / \mathrm{km}$ was logically assumed for the prograde part of the $P-T$ path.

In order to assess the P-T stability fields and the fluid behavior of the metaperidotite along the selected P-T path, we calculated $\mathrm{P}-\mathrm{T}$ and $\mathrm{P}(\mathrm{T})-\mathrm{X}_{\mathrm{CO} 2}$ phase diagram sections (pseudosections) for the bulk rock composition 1.95 $\mathrm{CaO}: 5.29 \mathrm{FeO}: 52.67 \mathrm{MgO}: 0.81 \mathrm{Al}_{2} \mathrm{O}_{3}: 39.67 \mathrm{SiO}_{2}$ (in weight amount) in the system CFMASCHO $\left(\mathrm{CaO}-\mathrm{FeO}-\mathrm{MgO}-\mathrm{Al}_{2} \mathrm{O}_{3}-\mathrm{SiO}_{2}-\mathrm{CO}_{2}-\mathrm{H}_{2} \mathrm{O}\right)(\mathrm{Figs} 4,5)$ and the results compared with observed phase relationships in the rocks. Calculations were performed with the software Perplex (ver.06 Jul 2006). The thermodynamic database of Holland and Powell (1998, revised 2002) 

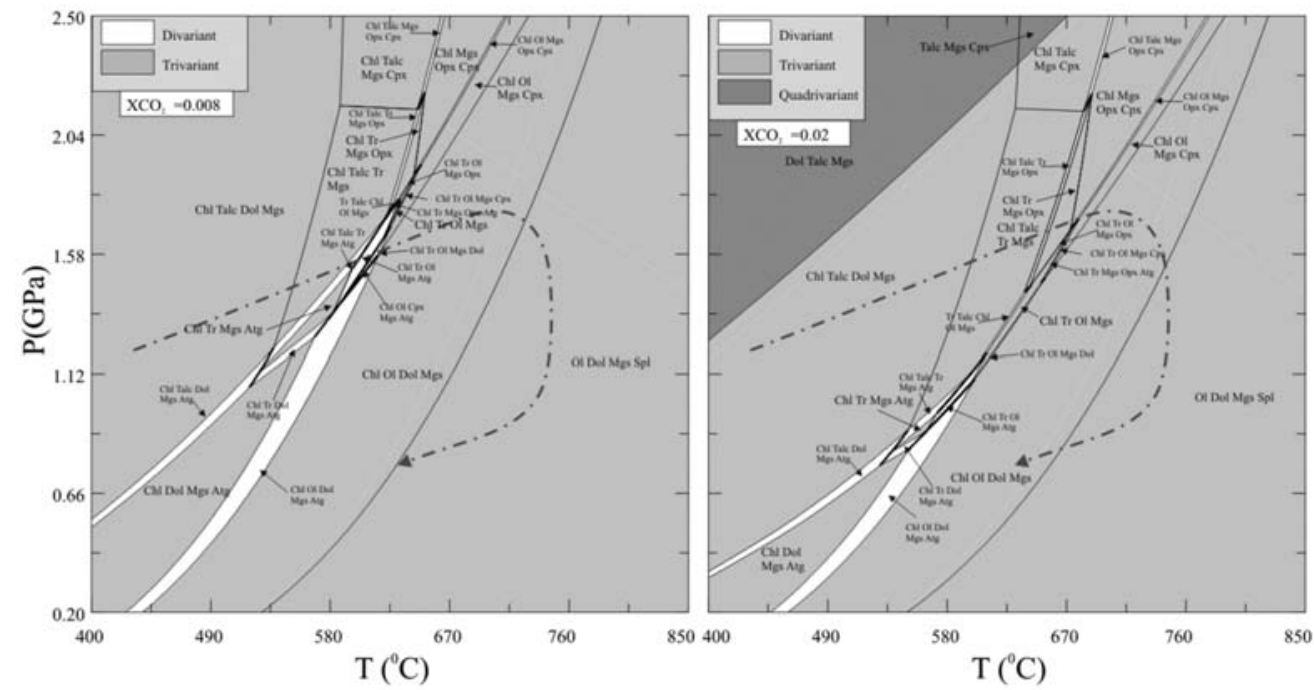

Fig. 4: Pressure-temperature phase diagram sections in the system CFMASCH $\left(\mathrm{CaO}-\mathrm{FeO}-\mathrm{MgO}-\mathrm{Al}_{2} \mathrm{O}_{3}-\mathrm{SiO}_{2}\right.$ $\mathrm{CO}_{2}-\mathrm{H}_{2} \mathrm{O}$ ) computed with Perplex software (version Perplex 06; Connolly 2009) for: a) $\mathrm{X}_{\mathrm{CO}_{2}}=0.008$ and (b) $\mathrm{X}_{\mathrm{CO} 2}=0.02$. The parts of the univariant reactions "seen" by the bulk composition are indicated by heavy solid lines. A tentative P-T path similar to a geothermal gradient of $12^{\circ} \mathrm{C} / \mathrm{km}$ is drawn with a dotted-dashed line.

and solution models for antigorite, orthopyroxene, clinopyroxene, olivine, talc, spinel, dolomite and magnesite, chlorite and tremolite are incorporated into the Perplex software package of Connolly (2009). The fluid phase was calculated as a mixture of $\mathrm{CO}_{2}-\mathrm{H}_{2} \mathrm{O}$.

In carbonate-bearing ultramafic rocks, olivine forming reactions that consume antigorite require the presence of fluid phase low in $\mathrm{X}_{\mathrm{CO} 2}$. At $1.0 \mathrm{GPa}$ the reactions:

$$
\mathrm{Atg}+\mathrm{Mgs} \rightarrow \mathrm{Ol}+\mathrm{H}_{2} \mathrm{O}+\mathrm{CO}_{2}(1) \text { and } \mathrm{Atg}+\mathrm{Dol} \rightarrow \mathrm{Ol}+\mathrm{Tr}+\mathrm{H}_{2} \mathrm{O}+\mathrm{CO}_{2}
$$

occur if the $\mathrm{X}_{\mathrm{CO} 2}$ in the fluid phase is $<0.02$ and decreases significantly at high pressures (Figs. $4 \mathrm{a}, \mathrm{b})$. At higher $\mathrm{X}_{\mathrm{CO} 2}$ antigorite reacts to form talc and magnesite by the reaction:

$$
2 \mathrm{Atg}+45 \mathrm{CO}_{2} \rightarrow 17 \mathrm{Tlc}+45 \mathrm{Mgs}
$$

and olivine can be formed by the reaction:

$$
\mathrm{Tlc}+5 \mathrm{Mgs} \rightarrow 4 \mathrm{Ol}+\mathrm{H}_{2} \mathrm{O}+5 \mathrm{CO}_{2}
$$

Thus, we project the P-T pseudosections for very low values of fixed $\mathrm{CO}_{2}$ activity $\left(\mathrm{aCO}_{2}=0.008\right.$ and 0.02 ). $\mathrm{P}(\mathrm{T})-\mathrm{X}_{\mathrm{CO} 2}$ pseudosection for a geothermal gradient $\sim 12^{\circ} \mathrm{C} / \mathrm{Km}$ is calculated in order to reveal the nature of the fluid phase around the peak of metamorphism; this geothermal gradient results from the calculated P-T conditions of the associated eclogites. Because of our incomplete knowledge of thermodynamic properties of $\mathrm{Cr}$ and $\mathrm{Fe}^{3+}$ endmembers and their Margules parameters in the various solid solutions, our model system is $\mathrm{Cr}-\mathrm{Fe}^{3+}$-free. Hence, the stability fields calculated will shift for the true rock composition to the degree that chromium and ferric iron is relevant in the pertinent phases (e.g. spinel). Ti-clinohumite and ilmenite are not included in the calculations. Due to the above reasons, our calculations represent a first-order approximation of the model system. 
Inspection of the figure 4 shows that the main reactions, represented by narrow trivariant and divariant fields and some univariant lines, delimit the stability of antigorite, talc, tremolite, orthopyroxene, olivine and spinel. With increasing temperature the successive formed minerals are tremolite, orthopyroxene, clinopyroxene, olivine and dolomite at high pressures and antigorite, tremolite, olivine, dolomite and spinel at lower pressures. Chlorite is stable at a wide P-T field and is decomposed to spinel+olivine at high temperatures. At $\mathrm{X}_{\mathrm{CO} 2}=0.02$ the coexistence of orthopyroxene + olivine imply minimum pressure of $1.46 \mathrm{GPa}$ at $635^{\circ} \mathrm{C}$ (Fig. $4 \mathrm{~b}$ ). With decreasing $\mathrm{X}_{\mathrm{CO} 2}$ in fluid phase the orthopyroxene stability field is shifted toward higher pressures (Fig. 4a).

The presence of talc, chlorite, magnesite, dolomite and antigorite inclusions in ferrit-chromite, of magnesite, dolomite, chlorite, tremolite, talc and ferrit-chromite inclusions in olivine, and of magnesite, dolomite, chlorite, tremolite and olivine (Ol-1) inclusions in orthopyroxene indicate that the earliest assemblage was talc + chlorite + magnesite + dolomite, with tremolite and antigorite formation before olivine growth and orthopyroxene formation after olivine growth (O1-1).

For the selected P-T path and for $\mathrm{X}_{\mathrm{CO} 2}<0.008$ in the fluid phase, the formation of orthopyroxene in the Gorgona metaperidotite is not expected (see figure 4a). Orthopyroxene can be expected if we assume an increase in $\mathrm{X}_{\mathrm{CO} 2}$ in the fluid phase. The selected P-T path crosses the orthopyroxene stability field if $\mathrm{X}_{\mathrm{CO} 2}>0.02$ (Fig. 4b). However, at $\mathrm{X}_{\mathrm{CO} 2}>0.02$ (Fig. 4b) the antigorite is not expected and orthopyroxene comes earlier than olivine, but this is not in accordance with our petrographic observations.

In closed system, the $\mathrm{X}_{\mathrm{CO} 2}$ value increases by the antigorite and olivine forming reactions 3 and 4 . Reaction 3 produces only $\mathrm{CO}_{2}$ whereas reaction 4 produces more $\mathrm{CO}_{2}$ than $\mathrm{H}_{2} \mathrm{O}$.

Based on the textural relationships, $\mathrm{P}-\mathrm{T}$ path and $\mathrm{P}(\mathrm{T})-\mathrm{X}_{\mathrm{CO} 2}$ estimation, it seems that the mineral assemblages in the Gorgona metaperidotite, are formed in two equilibrium stages; a prograde stage and a decompression stage of metamorphism.

\section{Prograde stage:}

The inclusions of magnesite, dolomite, chlorite, talc tremolite in olivine, and magnesite, dolomite, chlorite, tremolite in orthopyroxene indicate that the prograde path of metamorphism crossed the stability fields of Dol+Mgs+Tlc+Chl and $\mathrm{Tr}+\mathrm{Tlc}+\mathrm{Mgs}+\mathrm{Chl}$ before the formation of olivine and orthopyroxene. The rare inclusions of antigorite in ferrit-chromite inclusions in olivine show that the prograde path also crossed the antigorite stability field.

For the selected geothermal gradient of $12^{\circ} \mathrm{C} / \mathrm{km}$, the prograde path crosses the stability field of $\mathrm{Tr}+\mathrm{Mgs}+\mathrm{Tlc}+\mathrm{Chl}$ if $\mathrm{X}_{\mathrm{CO} 2} \geq 0.0075$ (Fig. 5a). Tremolite is formed by the reaction:

$$
2 \mathrm{Tlc}+2 \mathrm{Dol} \rightarrow \mathrm{Tr}+3 \mathrm{Mgs}+\mathrm{H}_{2} \mathrm{O}+\mathrm{CO}_{2}
$$

without changes in the mole fraction of the primary $\mathrm{X}_{\mathrm{CO} 2}$ value. With increasing pressure and temperature, the P-T path meets the boundary of the trivariant $\mathrm{Chl}+\mathrm{Mgs}+\mathrm{Tr}+\mathrm{Tlc}$ and the divariant $\mathrm{Chl}+\mathrm{Tlc}+\mathrm{Tr}+\mathrm{Atg}+\mathrm{Mgs}$ field and antigorite is formed at the expense of talc and magnesite according to the divariant reaction:

$$
\mathrm{Mgs}+\mathrm{Tlc} \rightarrow \mathrm{Atg}+\mathrm{CO}_{2}
$$

As the P-T path moved along this boundary, the modal antigorite increases up to the pseudo-invariant point $\mathrm{A}$, where $\mathrm{Chl}+\mathrm{Tr}+\mathrm{Tlc}+\mathrm{Mgs}+\mathrm{Atg}+\mathrm{Ol}$ is stable and olivine is formed according to the univariant and divariant reactions respectively: 


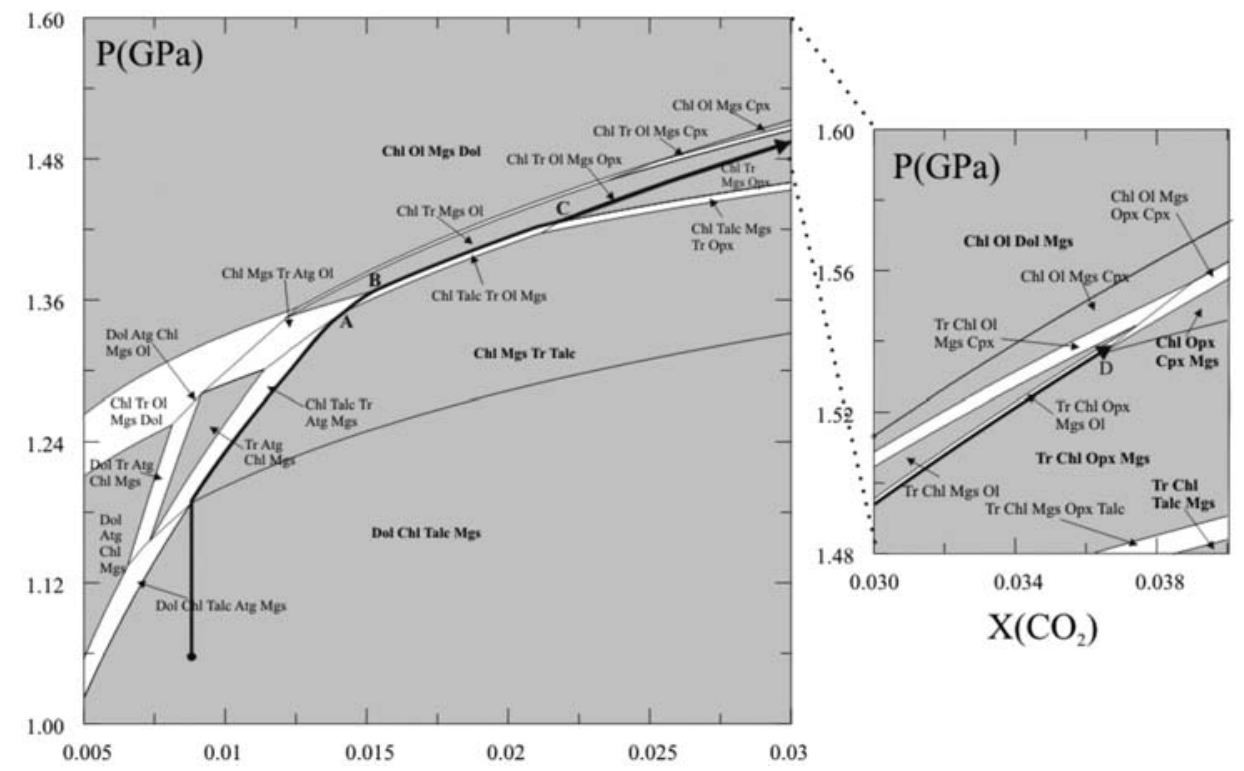

Fig. 5: P/T-X sections for (a) $\mathrm{X}_{\mathrm{CO} 2} 0.005-0.03$ and (b) $\mathrm{X}_{\mathrm{CO} 2}$ 0.03-0.04 in the system CFMASCH. The internal buffering fluid evolution (bold arrow) and the divariant reactions along the prograde P-T path shown in Fig. 4 are illustrated. Assemblages' stability fields as in figure 4 . A geothermal gradient of $12^{\circ} \mathrm{C} / \mathrm{km}$ is considered along the vertical axes.

$$
\mathrm{Atg}+\mathrm{Mgs} \rightarrow \mathrm{Tlc}+\mathrm{Ol}+\mathrm{CO}_{2}(7) \text { and } \mathrm{Mgs}+\mathrm{Atg} \rightarrow \mathrm{Ol}+\mathrm{CO}_{2}+\mathrm{H}_{2} \mathrm{O}
$$

With further increase of pressure and temperature the reactions move along the boundary of the divariant $\mathrm{Chl}+\mathrm{Mgs}+\mathrm{Tr}+\mathrm{Atg}+\mathrm{Ol}$ and $\mathrm{Chl}+\mathrm{Tlc}+\mathrm{Tr}+\mathrm{Mgs}+\mathrm{Ol}$ fields where antigorite and magnesite are consumed to form more olivine and talc up to the pseudo-invariant point $\mathrm{B}$ which records the maximum P-T- $\mathrm{X}_{\mathrm{CO} 2}$ conditions for the antigorite stability in the metaperidotite along the selected P-T path. As prograde metamorphism advances, the reactions move along the boundary of the divariant $\mathrm{Chl}+\mathrm{Tlc}+\mathrm{Tr}+\mathrm{Ol}+\mathrm{Mgs}$ and trivariant $\mathrm{Chl}+\mathrm{Tr}+\mathrm{Mgs}+\mathrm{Ol}$ fields consuming magnesite and talc and forming more olivine up to the pseudo-invariant point $\mathrm{C}$. At the pseudo-invariant point $\mathrm{C}$ (Fig. 5a) at $\mathrm{P}$ $(1.42 \mathrm{GPa}), \mathrm{T}\left(635^{\circ} \mathrm{C}\right)$ and $\mathrm{X}_{\mathrm{CO} 2}(0.022)$ talc, olivine and magnesite react to form orthopyroxene, chlorite and fluid phase according to the reaction:

$$
\mathrm{Tlc}+\mathrm{Ol}+2 \mathrm{Mgs} \rightarrow \mathrm{Opx}+\mathrm{Chl}+2 \mathrm{CO}_{2}+\mathrm{H}_{2} \mathrm{O}
$$

which is in accordance with the textural relationship where olivine inclusions in orthopyroxene show resorbed edges and chlorite inclusions are common in orthopyroxene megacrysts. With continuing prograde path the reactions proceed along the boundary of the trivariant assemblages $\mathrm{Chl}+\mathrm{Tr}+\mathrm{Mgs}+\mathrm{Opx}$ and $\mathrm{Chl}+\mathrm{Tr}+\mathrm{Mgs}+\mathrm{Ol}$ and olivine is formed consuming orthopyroxene. Rare orthopyroxene inclusions in olivine (Fig. 2f) indicate that the prograde path exceeded the P-T- $\mathrm{X}_{\mathrm{CO} 2}$ conditions of point C (Fig. 5).

P-T- $\mathrm{X}_{\mathrm{CO} 2}$ conditions did not reach the pseudo-invariant point $\mathrm{D}$ (Fig. 5b), where the assemblage $\mathrm{Tr}+\mathrm{Chl}+\mathrm{Ol}+\mathrm{Opx}+\mathrm{Mgs}+\mathrm{Cpx}$ is stable as clinopyroxene is not formed in the metaperidotite. For the selected P-T path the peak metamorphic conditions are constrained between $1.42 \mathrm{GPa}$ and $640^{\circ} \mathrm{C}$ and $1.53 \mathrm{GPa}$ and $688^{\circ} \mathrm{C}$ (points $\mathrm{C}$ and $\mathrm{D}$ respectively in figure 5). 


\section{Decompression stage:}

As discussed above, at the maximum P-T conditions, the prograde path crossed neither the $\mathrm{Ol}+\mathrm{Dol}+\mathrm{Mgs}+\mathrm{Spl}$ nor the $\mathrm{Chl}+\mathrm{Ol}+\mathrm{Mgs}+\mathrm{Dol}$ trivariant field. However matrix dolomite and spinel are common phases in the metaperidotite. Both mineral phases can be formed during decompression. In eclogites, the first stage of decompression is indicated by a temperature increase up to $750^{\circ} \mathrm{C}$ (Bauer et al. 2007). Following a decompression path similar to that recorded in the associated eclogites, dolomite is formed before the decomposition of chlorite to olivine+spinel (Fig. 4b). This is in accordance with textural relations as commonly matrix dolomite contains inclusions of chlorite (Chl1). Spinel is formed as the decompression path crosses the univariant reaction:

$$
\mathrm{Chl}+2 \mathrm{Mgs} \rightarrow \mathrm{Spl}+3 \mathrm{Ol}+4 \mathrm{H}_{2} \mathrm{O}+2 \mathrm{CO}_{2}
$$

However textural relationships indicate that spinel associates with olivine (Ol-2) and Al-tremolite and not with primary magnesite (Mgs-1). We propose that in the spinel forming reaction dolomite is involved in the reacting phases with the most possible reaction

$$
\mathrm{Chl}+\mathrm{Dol} \rightarrow \mathrm{Ol}+\mathrm{Spl}+\mathrm{Al}-\mathrm{Tr}+\mathrm{H}_{2} \mathrm{O}+\mathrm{CO}_{2}
$$

Amphibole is not stable with spinel in the calculated pseudosections with the bulk rock composition of the studied metaperidotite. However, amphibole can coexist with olivine and spinel if we take into account the effective bulk composition (richer in $\mathrm{SiO}_{2}$ content) obtained by subtracting clinohumite, ilmenite and the inclusions in olivine and orthopyroxene megacrysts. Ti-clinohumite with $\mathrm{X}_{\mathrm{F} 0.12-0.14}$ was stable at the peak P-T metamorphic conditions (Fig. 4b) and was decomposed to olivine $+\mathrm{Mg}$ ilmenite (Fig. 3a) during decompression according to the reaction:

$$
\mathrm{Ti}-\mathrm{Chu}\left(\mathrm{X}_{\mathrm{F} 0.14}\right) \rightarrow \mathrm{Ol}+\mathrm{Mg}-\mathrm{Ilm}+\mathrm{H}_{2} \mathrm{O}+\mathrm{F}
$$

\subsection{Tectonic implications}

The inclusions of magnesite, chlorite, talc, antigorite, tremolite and Cr-magnetite in olivine, orthopyroxene and ferrit-chromite and the chemical composition of zoned spinel minerals with increasing Al-content from the core to the rim indicate that the carbonate-bearing metaperidotite from Gorgona underwent a prograde (HP) metamorphism in a subduction-related setting.

A major concern is the way in which this mantle fragment was incorporated into the subducting slab. Two scenarios can be invoked. Either it represents a piece of former ophiolite mélange and was tectonically incorporated into the crustal assemblage prior to subduction, or it represents a piece of former mantle wedge above an early Jurassic subduction zone incorporated into the subduction channel by a tectonic erosion mechanism, because of hydration from fluids liberated from the subducting oceanic slab (Von Huene et al., 2004). The subcontinental mantle origin is preferred, because the Gorgona metaperidotite is surrounded by gneissic rocks with no sign of oceanic affiliation. The prograde P-T path is clearly constrained to pressure and temperature below 1.5-1.7 GPa and 690-720. ${ }^{0} \mathrm{C}$ by the absence of the clinopyroxene. This indicates that peak P-T conditions were lower than those recorded in the Jurassic eclogites $\left(>1.75 \mathrm{GPa}\right.$ and $700^{\circ} \mathrm{C}$, Bauer et al. 2007) and much lower than those recorded in the Jurassic diamond-bearing Grt-Ky gneisses $\left(>4 \mathrm{GPa}\right.$ and $\sim 1000^{\circ} \mathrm{C}$, Mposkos and Krohe, 2006). If the mineral assemblage of the Gorgona metaperidotite was formed during the Mesozoic metamorphic cycle then it was subducted to (much) lower depth within the subduction channel than the associated eclogites and diamond-bearing gneisses. 


\section{Conclusions}

Mineral textures and compositions, $\mathrm{P}-\mathrm{T}$ and $\mathrm{P}(\mathrm{T})-\mathrm{X}_{\mathrm{CO} 2}$ phase diagram calculations show that the Gorgona carbonate-bearing metaperidotite is a mantle-derived, metamorphosed tectonic slice, which was subjected to a prograde HP metamorphism. The prograde path crossed successive the stability fields of Dol+Tlc+Mgs+Chl, Tr+Tlc+Mgs+Chl, Tr+Atg+Tlc+Mgs+Chl, Tr+Mgs+Atg+Ol+Chl, $\mathrm{Tr}+\mathrm{Chl}+\mathrm{Mgs}+\mathrm{Ol}$ and at the maximum $\mathrm{P}-\mathrm{T}$ conditions the field of $\mathrm{Ol}+\mathrm{Opx}+\mathrm{Mgs}+\mathrm{Tr}+\mathrm{Chl}$. The intruded fluids had a composition rich in $\mathrm{H}_{2} \mathrm{O}$ with $\mathrm{X}_{\mathrm{CO}_{2}} \leq 0.008$. During the prograde metamorphism the $\mathrm{X}_{\mathrm{CO} 2}$ in the fluid phase increased as magnesite consuming and antigorite, olivine and orthopyroxene forming reactions produced much more $\mathrm{CO}_{2}$ that $\mathrm{H}_{2} \mathrm{O}$. The increase in $\mathrm{X}_{\mathrm{CO} 2}$ in the fluid phase was responsible for the orthopyroxene formation. Decomposition of Ti-clinohumite to olivine and $\mathrm{Mg}$-ilmenite and of chlorite to olivine and high Al-chromite occurred during decompression. Retrograde chlorite (Chl-2) associated with magnesite (Mgs-2) and replacing spinel and olivine (Fig. 2c) and retrograde talc and tremolite are formed by a second metamorphic event according to reactions 4, 9 and 10 within the stability field of $\mathrm{Tr}+\mathrm{Chl}+\mathrm{Tlc}+\mathrm{Mgs}$. The reactions require intrusion of a fluid phase. Such fluids can be derived from metamorphic reactions occurred in the underlying Albite-Gneiss Series which underwent prograde HP metamorphism in early Tertiary (Mposkos and Krohe, 2000; Lips et al., 2000).

We suggest that the Gorgona carbonate-bearing metaperidotite represents a fragment of the hydrated mantle wedge and it was incorporated into the subduction channel with a tectonic erosion mechanism in early Jurassic.

\section{References}

Bauer, C., Rubatto, D., Krenn, K., Proyer, A. and Hoinkes, G. 2007. A zircon study from the Rhodope metamorphic complex, N-Greece: Time record of a multistage evolution. Lithos, 99, 207-228.

Bosse, V., Boulvais, P., Gautier, P., Tiepolo, M., Ruffet, G., Devidal, J.L., Cherneva, Z., Gerdjikov, I. and Paquette, J.L., 2009. Fluid-induced disturbance of the monazite Th-Pb chronometer: In situ dating and element mapping in pegmatites from the Rhodope (Greece, Bulgaria). Chemical geology 261, 3-4, 286-302.

Connolly, J. A. D. 2009. The geodynamic equation of state: what and how. Geochemistry, Geophysics, Geosystems, 10, QXXXX. DOI: 10.1029/2009GC002540.

Evans, B.W. and Frost, B.R. 1975. Chrome-spinel in progressive metamorphism-a preliminary analysis. Geochimica et Cosmochimiica Acta, 39, 959-972.

Holland, T., Baker, J. and Powell, R. 1998. Mixing properties and activity-composition relationships of chlorites in the system MgO-FeO-A12O3-SiO2-H2O. European Journal of Mineralogy, 10, 395-406.

Holland, T. J. B. H. and Powell, R. 1996. Thermodynamics of order-disorder in minerals.2. Symmetric formalism applied to solid solutions. American Mineralogist, 81, 1425-1437.

Holland, T. J. B. H. and Powell, R. 1998. An internally consistent thermodynamic data set for phases of petrological interest. Journal of Metamorphic Geology, 16, 309-343.

Kassoli-Fournaraki, A., Filippidis, A., Kolcheva, K., Hatzipanayotou, K., Koepke, J. and Dimadis, E. 1995. Multi-stage alteration of the Gorgona ultramafic body, Central Rhodope Massif, Greece. Chemie der Erde, 55, 331-340.

Krohe, A. \& Mposkos, E. 2002. Multiple generations of extensional detachments in the Rhodope Mountains (N.Greece): evidence of episodic exhumation of high-P rocks. In: Blundell, D.J., 
Neubauer, G. and Von Quant, A. (eds.): The timing and location of major ore deposits in an evolving orogen. Geological Society of London, Special Publication, 204, 151-178.

Liati, 2005. Identification of repeated Alpine (ultra) high-pressure metamorphic events by U-pb SHRIMP geochronology and REE geochemistry of zircon: the Rhodope zone of Northern Greece, Contributions to Mineralogy and Petrology, 150, 608-630.

Liati,A. and Mposkos, E. 1990. Evolution of the eclogites in the Rhodope Zone of northern Greece, Lithos, 25, 89-99.

Lips, A.L.W., White, S.H. and Wijbrans, J.R. 2000. Middle-Late Alpine thermotectonic evolution of the southern Rhodope Massif, Greece. Geodinamica Acta, 13, 281-292.

Martin, R.F. 1998. Symbols of the rock-forming minerals. The Nomenclature of minerals: A compilation of IMA reports. IMA`98 Toronto, 148-149.

Mposkos, E. and Kostopoulos, D. 2001. Diamond, former coesite and supersilicic garnet in metasedimentary rocks from the Greek Rhodope: a new ultrahigh-pressure metamorphic province established. Earth and Planetary Science Letters, 192, 497-506.

Mposkos, E. and Krohe, A. 2000. Petrological and structural evolution of continental high pressure (HP) metamorphic rocks in the Alpine Rhodope domain (N.Greece). Proceedings of the 3rd International Conference on the Geology of the Eastern Mediterranean, 221-232.

Mposkos, E. and Krohe, A. 2006. P-T-deformation paths of closely associated UHP (diamond-bearing) crustal and mantle rocks of the Kimi Complex: Implications for the tectonic history of the Rhodope Mountains, northern Greece. Canadian Journal of Earth Sciences, 43, 1755-1776.

Perraki, M., Proyer, A., Mposkos, E., Kaindl, R., Baziotis, I. and Hoinkes, G. 2004. Micro- and nanodiamonds in garnets of metapelitic rocks from the Greek Rhodope : an in situ micro-Raman study. Proceedings of the 5th International Symposium for Eastern Mediterranean Geology, 1216-1219.

Perraki, M., Proyer, A., Mposkos, E., Kaindl, R. and Hoinkes, G. 2006. Raman micro-spectroscopy on diamond, graphite and other carbon polymorphs from the ultrahigh-pressure metamorphic Kimi Complex of the Rhodope Metamorphic Province, NE Greece. Earth and Planetary Science Letters, 241, 672-685.

Von Huene, R., Ranero, C.R. and Vannucchi, P. 2004. Generic model of subduction erosion. Geology, 32, 913-916. 